\title{
Influence of Seeds Soaking with Benzyladenine, Paclobutrazol, Algae Extract, Some Mineral Nutrients and Lithovit on Seeds Germination and Seedling Growth of Moringa olifera Plant.
}

Abd El-Dayem, H. M.; Faten H. M. Ismaeil; Abd El-Aal, M. M. M. and Rania S. M. Eid

Agricultural Botany Dept., Fac. of Agric., Benha University, Egypt.

Corresponding Author: hosny.abdeldaim@fagr.bu.edu.eg

\begin{abstract}
Two laboratory experiments were conducted out at Agricultural Botany Department, Faculty of Agriculture, Moshtohor, Benha University, Qalyubia Governorate, Egypt, during two successive seasons of 2016 and 2017. The objective of this study was to evaluate the effect of soaking of seed with benzyl adenine (BA) at (25, 50 and $\left.100 \mathrm{mgl}^{-1}\right)$, paclobutrazol $\left(\mathrm{PP}_{333}\right.$ at $\left(5,10\right.$ and $\left.20 \mathrm{mgl}^{-1}\right)$, algae extract at $\left(5,10\right.$ and $\left.20 \mathrm{ml}^{-1}\right)$, mineral nutrients $(\mathrm{Ca}$, $\mathrm{Mg}$ and Fe chelated) at $500 \mathrm{mgl}^{-1}$ and treatment of lithovit at $500 \mathrm{mgl}^{-1}$ on seed germination (percentage, rate) and seedling growth of Moringa oleifera plant.

The obtained results reported that seed soaking with benzyl adenine (BA) at different tested concentrations enhanced seed germination and seedlings growth traits during the two seasons of study. Also, soaking seeds in $100 \mathrm{mgl}^{-1}$ benzyl adenine (BA) reflected the highest values of seed germination (rate and percentage) as well as growth of seedling measurements i.e., The radical and plumule lengths at 7, 10 and 13 days from soaking and absolute growth rate of root and stem after 10 and 13 days of seed treating followed by using lithovit at $500 \mathrm{mgl}^{-}$ 1, Algae extract at $20 \mathrm{mll}^{-1}$, benzyl adenine (BA) at $50 \mathrm{mgl}^{-1}$., mineral elements at $500 \mathrm{mgl}^{-1}$ and benzyl adenine the at the lowest concentration i.e., $25 \mathrm{mgl}^{-1}$ in descending order.

On contrary, germination of seeds and seedlings growth traits were significantly decreased with paclobutrazol treatments in both seasons compared with the control treatment.
\end{abstract}

Key words: moringa, benzyl adenine, paclobutrazol, algae extract, lithovit and seed germination.

\section{Introduction}

Moringa oleifera Lama is a species of mono generic Family Moringaceae, contains 13 species of trees and shrubs (Fahey 2005). Moringa oleifera is a crucial food commodity with a great deal of attention as a natural food for the tropics and subtropics. Various parts (leaves, fruit, flowers and immature pods) of this plant are used as a highly nutritious vegetable in many countries (Anwar et al., 2005). Also, it has an amazing range of medicinal uses owing to its high nutritional rate.

Moringa leaves have been reported to be a rich source of protein, vitamins, B-carotene, essential minerals ( $\mathrm{Ca}$ and $\mathrm{K}$ ), amino acids and a variety of phenolic compounds serving as a respectable source of natural antioxidants such as as ascorbic acid, flavonoids, phenolics and carotenoids (Siddhuraju and Becker 2003 ). Moringa is sexually distributed through the seeds and vegetatively through the stem cuttings (Palada and Chang 2003).

Its germination percentage varies between $60 \%$ and $90 \%$ for fresh seed (Jahn et al., 1986) and germinates between 7 and 30 days after planting (Sharma and Raina 1982). Cultivation of moringa by seed is troublesome as seeds typically begin to lose viability within 2 months of storage. (Sharma and Raina 1982) recorded 60 percent, 48 percent and 7.5 percent germination of moringa seed after 1, 2 and 3 months of selection. Old moringa seed has problems with germination due to high oil content and insect attacks. There is a strong need to investigate ways to solve germination problems in Moringa seeds (Ahmed et al., 2014).
Various priming techniques have been developed to promote plants, such as hydropriming, osmopriming, matripriming, hardening, osmohardening, and hormonal primers (Basra et al., 2005) and (2006), respectively (Afzal $\boldsymbol{e t}$ al., 2008). Main therapy decreases the date of onset and raises the percentage of final onset and onset index (Farooq et al., 2005), (2006b) and (2008). They also organize the emergence of seeds which result in even-handed growth and increased yield (Du and Tuong 2002); (Harris et al., 2002). (Tedonkeng et al., 2004) described that germination of older moringa seeds can also be enhanced by freshwater soaking, but no detailed research analysis on the consequences of different seed primers was published earlier on techniques of the emergence and seedling of moringa.

Consequently, it is important to find ways to disperse the plant rapidly, allowing farmers to maximize their production potential. The main objective of this research is therefore to investigate the effects of benzyl adenine, paclobutrazole, algae extract, mineral elements ( $\mathrm{Ca}, \mathrm{Mg}$ and $\mathrm{Fe}$ chelated) and lithovit on seed germination percent and rate, as well as the seedling strength guide for Moringa oliefera plant.

Cytokinins are plant hormones, which control a variety of plant behavior, including seed germination (Graeber et al., 2012). They are active in all germination cycles (Chiwocha et al., 2005), (Nikolic et al., 2006), (Riefler et al., 2006 ). They can also influence the behaviors of meristemic cells in roots and shoots during the germination process.

Various activities of cytokinins, such as their effects on seed germination, have been qualified for 
many roles of cytokines in various cell types. Plant hormones with cytokines are biological compounds that regulate a broad variety of physiological and biochemical reactions in plant life (Werner et al., 2001). Nanotechnology is a hopeful field of interdisciplinary research. It opens up a wide range of opportunities in various fields including agriculture. The potential applications and benefits of nanotechnology are wide. Nanoparticles produce both positive and negative biological results in living cells (Nel et al., 2006). There is a growing volume of research into the biological impact of nanoparticles on higher plants. Similarly, mixture of nanoscales hastened germination in soybean (Lu et al., 2002). Prasad et al., (2012) found that the treatment of nanoscales facilitated seed germination and seedling intensity and was successful in growing stem and root growth. (Hojjat 2015) suggest that nanoscales at their lower stage minimize Speed of germination, percent germination and earlier seedling growth in Fenugreek.

Paclobutrazol $\left(\mathrm{PP}_{333}\right)$ is an effective plant growth retardant for use of the Plant Growth Control Society of America (PGRSA 2007). It plays a strong regulatory function in plant development. Paclobutrazol inhibits growth by inhibiting the biosynthesis of gibberellin (Rademacher 2000). Marshall et al., (2000) reported that treatment of fresh silver maple seeds with paclobutrazol late germination and decrease root and shoot extension. Also, Mijajlović et al., (2005) reported that paclobutrazole as a growth retardant-caused inhibition of centaury (Centaurium erythraea rafn) seed germination. Müller (2007) achieved reproducible results of paclobutrazol on the inhibition of seed germination of Townsville stylo (Stylosanthes humilis).

Algae extract has been promoted for several years as fertilizer additives and helpful results from their use have been reported (Ahmed and Shalaby 2012).

The importance of the extract of algae as a biofertilizer was due not only to the content of nitrogen, phosphorus and potassium, but also to the presence of trace elements and metabolites. These extracts enhance the germination of seeds and the absorption of nutrients by plants. The extract also includes phytohormones IAA, IBA, cytokinins, other trace elements $(\mathrm{Fe}, \mathrm{Cu}, \mathrm{Zn}$, $\mathrm{Co}, \mathrm{Mo}, \mathrm{Mn}, \mathrm{Ni})$, Several vitamins and amino acids (Durand et al., 2003), (Stirk et al., 2003) and (Ördög et al., 2004). Many experiments have demonstrated a wide variety of beneficial effects of algae extract submissions on plants, such as promoting the germination of watermelon and sesame seeds (Sunarpi et al., 2007).

Algae extract was able to increase the growth as a result of enhancement of protein biosynthesis and cell division, and mobilization of elements needing for growth (Pascale et al., 1993).

\section{Material and Methods}

The present investigation was carried out during the two successive seasons of 2016 and 2017 at laboratory of Agricultural Botany Department, Faculty of Agriculture, Moshtohor, Benha University.

The main objective of this research was to study the effect of benzyl adenine, paclobutrazole, algae extract, some mineral elements and Lithovit on the germination of seeds, the growth of seedlings (rate and percentage) and the growth of Moringa oleifera plants.

I.Source of seeds, algae extract and lithovit:

Moringa oleifera Seeds were brought from the National Research Centre, Dokki. Giza, Egypt.

Algae extract was obtained from the Algael Biotechnology Unit, National Research Center, Dokki, Giza, Egypt, and prepared by dissolving 5, 10 and $20 \mathrm{ml}^{-1}$ of water. Lithovit as Nano-Particles (Calicum, Magnesium and Iron Nano or MicroParticles) was acquired from the Agro-Link Firm (3 Ibn-Eyas. St., Roxy, Heliopolis, Cairo).

Lithovit was used in the German industrial commodity by Zeovito Company. The solution was prepared by dissolving $0.5 \mathrm{~g} / \mathrm{L}$ of distilled water.

This experiment was done in laboratory by using $10 \mathrm{~cm}$ diameter petri dishes. Seeds of Moringa oleifera were soaked four hours in the following assigned treatments.

The applied treatments as following:

1- Control (distilled water)

2- Benzyl adenine at 25, 50 and $100 \mathrm{mgl}^{-1}$

3- Paclobutrazol at 5, 10 and $20 \mathrm{mgl}^{-1}$

4- Algae extract at 5,10 and $20 \mathrm{mll}^{-1}$

5- Mineral nutrients ( $\mathrm{Ca}, \mathrm{Mg}$ and $\mathrm{Fe}$ chelated) at $500 \mathrm{mgl}^{-1}$

6- Lithovit (nanoparticles) at $500 \mathrm{mgl}^{-1}$

The seeds with uniform size and weight were chosen for the experimental study. The seeds surface were sterilized with $0.2 \% \mathrm{Hg} \mathrm{cl}_{2}$ solution for 5 minutes and washed thoroughly with distilled water.

Petri dishes $(10 \mathrm{~cm}$ in diameter) is sterilized and then filtered to hold moisture for the germination of the seeds.

\section{Soaking treatment:}

Thirty (30) moringa seeds were soaked in $200 \mathrm{ml}$ for each treatment and deposited for 4 hours for each treatment, on May 5 in both seasons.

Then, the seeds of different levels of each treatment were transferred into petri dishes, 10 seeds were placed in each petri dish at equal distance in 3 replicates and then these were incubated at room temperature. Also, filter papers were kept always wet. Maintaining sufficient moisture, $5 \mathrm{ml} /$ petri distilled dishes are taken as a control.

\section{Collection of data for germination and growth parameters as follows:}

Data for day-to-day germination of seed was collected before germination is done (maximum up to 13 days). Seeds with a growth rate of $0.5 \mathrm{~mm}$ or more have been counted as germinated seeds.

Every three days, the germination in each replicate 
was removed from the petri dishes for measurements of radical and plumule length till the end of the experiment (13 days).

\section{Then the following measurements were estimated:} 1- The Germination percentage:

The Germination percentage of seeds was calculated as the method described by (Scott $\boldsymbol{e t}$ al., 1984) as germinated seeds from the total seed of each treatment on the day of completion according to the following equation:

$$
\text { Germination } \%=\frac{\text { Number of the germinated seeds }}{\text { Number of total seeds }} \times 100
$$

\section{2- Germination rate:}

Data of germination rate were recorded at three periods, (4, 6 and 8 days) from soaking. Germination rate was expressed as the mean number of days required for germination ( $\mathrm{M}$ days) according to the formula of (Edmond and Drapala 1958):

$\boldsymbol{M} \boldsymbol{d a y s}=\frac{(\mathrm{N} 1 \mathrm{XG} 1)+(\mathrm{N} 2 \mathrm{X} \mathrm{G} 2)+\cdots \ldots(\mathrm{Nn} \times \mathrm{Gn})}{\mathrm{G} 1+\mathrm{G} 2+\cdots \ldots \mathrm{Gn}}$

$\mathrm{N}_{1}=$ Number of days passed from soaking till first count.

$\mathrm{N}_{2}=$ Number of days passed from soaking till second count to $\mathrm{N}_{n}$. $\mathrm{G}_{1}=$ Number of seeds germinated at the first count.

$\mathrm{G}_{2}=$ Number of germinated seeds at the second count........ to Gn.

\section{3- Root and stem length:}

The root and stem lengths were slow with the help of a thread and scale. Root length was measured from the point below the cotyledons to end of the tip root and stem length was taken from the point of cotyledons up to the plumule.

\section{4- Seedling vigour index:}

The seedling vigour index was calculated by using the formula according to (Abdul boki and Anderson 1973).

Seedling vigour index $=($ Average root length $\mathrm{cm}+$ Average stem length in $\mathrm{cm}$ ) $\mathrm{x}$ Germination percentage.

\section{5- Absolute growth rate of stem and root}

Absolute growth rate of stem and root were calculated according to the formula of (Cairo et al., 2008): $\mathbf{A G R}=\frac{(\text { PDWf }- \text { PDWi })}{(\text { tf }- \text { ti })}\left(\right.$ expressed in $\left.\mathrm{g} \mathrm{day}^{-1}\right)$, where PDWf and PDWi are the plant dry weights at the start and the end of the experiment, $t f$ and ti correspond to the final and initial period of the experiment in days.

\section{Statistical analysis:}

Data of seeds germination and seedlings growth were statistically analyzed and the means were compared by using the Least Significant Difference test (L.S.D) at 5\% level according to (Snedecor and Cochran 1989).

\section{Results}

1- Seed germination (percentage and rate) and seedling vigour index:

Data presented in Table (1) demonstrate the impact of seed soaking treatment with BA at $(25,50$ and $\left.100 \mathrm{mgl}^{-1}\right), \mathrm{PP}_{333}$ at $\left(5,10\right.$ and $\left.20 \mathrm{mgl}^{-1}\right)$, algae extract at $\left(5,10\right.$ and $\left.20 \mathrm{mll}^{-1}\right)$, mineral elements i.e. (Ca, $\mathrm{Mg}$ and $\mathrm{Fe}$ chelated) at $500 \mathrm{mgl}^{-1}$ and lithovit at $500 \mathrm{mgl}^{-1}$ for seed germination. (rate and germination percentage) and seedling vigour index of moringa grown under the laboratory conditions during the two seasons of 2016 and 2017. Herein, it was clear that soaking the seeds in benzyl adenine solution in different tested concentrations enhanced all forementioned seed germination and seedling vigour index during the two seasons of this study.

In this regard, the soaking seeds in $100 \mathrm{mgl}^{-1}$ benzyl adenine provided substantially higher seed germination rates and percentages as well as the seedling vigour index at 7,10 and 13 days following soaking in both study seasons accompanied by the use of lithovit at $500 \mathrm{mgl}^{-1}$, algae extract at $20 \mathrm{mll}^{-1}$, benzyl adenine at $50 \mathrm{mgl}^{-1}$, mineral elements at 500 $\mathrm{mgl}^{-1}$ and benzyl adenine at the lowest concentration $25 \mathrm{mgl}^{-1}$ in descending order when compared with the control treatment.

On the other hand, the soaking of seeds at various tested concentrations of paclobutrazol reduced seed germination (rate and percentage) and the seedling vigour index relative to control during both study seasons.

\section{2- Growth of seedlings (radical and plumule length):}

As shown in Table (2), different estimated growth characteristics of moringa seedlings (average radical and plumule length) grown in laboratory conditions treatment of seeds such as benzyl adenine at $(25,50$ and $\left.100 \mathrm{mgl}^{-1}\right)$, paclobutrazole at $\left(5,10\right.$ and $\left.20 \mathrm{mgl}^{-1}\right)$, algae extract at $\left(5,10\right.$ and $\left.20 \mathrm{ml}^{-1}\right)$, mineral elements i.e. $\left(\mathrm{Ca}, \mathrm{Mg}\right.$ and $\mathrm{Fe}$ chelated) at $500 \mathrm{mgl}^{-1}$ and lithovit at $500 \mathrm{mgl}^{-1}$ were affected during the two seasons of 2016 and 2017

Also, the same data illustrate that soaking seeds in benzyl adenine solution in different tested concentrations enhanced seedling radicals and plumule growths during both seasons of study. In this respect, soaking seeds in $100 \mathrm{mgl}^{-1}$ benzyl adenine gave the highest values of seedling growth measurements i.e., radical and plumule lengths at 7 , 10 and 13 days from soaking followed by using lithovit at $500 \mathrm{mgl}^{-1}$, algae extract at $20 \mathrm{mll}^{-1}$ and benzyl adenine at $50 \mathrm{mgl}^{-1}$ in descending order when compared with the control treatment.

The same data also confirmed the stimulatory and significantly effects of different applied treatments upon seedlings growth (radical and plumule lengths).

On the other side, soaking seeds in different tested concentrations of paclobutrazol decreased seedling growth parameters compared with the control treatment during the two seasons of study. 
Table 1. Effect of seed soaking treatments with benzyl adenine, paclobutrazol, algae extract, some elements $(\mathrm{Ca}$, $\mathrm{Mg}$ and $\mathrm{Fe}$ in chelated form) and lithovit on seeds germination (rate and percentage) and seedling vigour index of Moringa oleifera grown under laboratory conditions during seasons of 2016 and 2017.

\begin{tabular}{|c|c|c|c|c|c|c|c|c|c|}
\hline \multirow{3}{*}{\multicolumn{2}{|c|}{$\begin{array}{c}\text { Characteristics } \\
\text { Treatments }\end{array}$}} & \multicolumn{2}{|c|}{$\begin{array}{c}\text { Number of } \\
\text { germinated seeds }\end{array}$} & \multicolumn{2}{|c|}{$\begin{array}{c}\text { Germination } \\
\text { Rate }\end{array}$} & \multicolumn{2}{|c|}{$\begin{array}{c}\text { Germination } \\
\text { Percentage }(\%)\end{array}$} & \multicolumn{2}{|c|}{$\begin{array}{c}\text { Seedling } \\
\text { vigour index }\end{array}$} \\
\hline & & \multicolumn{8}{|c|}{ Seasons } \\
\hline & & 2016 & 2017 & 2016 & 2017 & 2016 & 2017 & 2016 & 2017 \\
\hline \multirow[t]{2}{*}{$\overline{\text { Control }}$} & 0.0 & 8 & 7 & 5.8 & 6.2 & 80 & 70 & 402 & 483 \\
\hline & $25 \mathrm{mgl}^{-1}$ & 9 & 8 & 4.8 & 5.4 & 90 & 80 & 594 & 662 \\
\hline \multirow[t]{3}{*}{ Benzyl adenine } & $50 \mathrm{mgl}^{-1}$ & 10 & 10 & 4.4 & 4.4 & 100 & 100 & 840 & 1040 \\
\hline & $100 \mathrm{mgl}^{-1}$ & 10 & 10 & 4.0 & 4.0 & 100 & 100 & 1200 & 1350 \\
\hline & $5 \mathrm{mgl}^{-1}$ & 7 & 6 & 6.4 & 7.0 & 70 & 60 & 263 & 320 \\
\hline \multirow[t]{3}{*}{ Paclobutrazol } & $10 \mathrm{mgl}^{-1}$ & 6 & 5 & 7.0 & 7.6 & 60 & 50 & 197 & 229 \\
\hline & $20 \mathrm{mgl}^{-1}$ & 4 & 3 & 7.8 & 7.8 & 40 & 30 & 111 & 121 \\
\hline & $5 \mathrm{mll}^{-1}$ & 8 & 7 & 5.2 & 6.0 & 80 & 70 & 442 & 525 \\
\hline \multirow[t]{2}{*}{ Algae extract } & $10 \mathrm{mll}^{-1}$ & 9 & 8 & 4.8 & 5.2 & 90 & 80 & 628 & 727 \\
\hline & $20 \mathrm{mll}^{-1}$ & 10 & 10 & 4.2 & 4.3 & 100 & 100 & 1010 & 1153 \\
\hline Elements & $500 \mathrm{mgl}^{-1}$ & 10 & 10 & 4.4 & 4.8 & 100 & 100 & 785 & 981 \\
\hline Lithovit & $500 \mathrm{mgl}^{-1}$ & 10 & 10 & 4.0 & 4.2 & 100 & 100 & 1096 & 1253 \\
\hline L.S.D. & 0.05 & 1.21 & 1.75 & 0.21 & 0.17 & 6.98 & 7.74 & 64.93 & 79.92 \\
\hline
\end{tabular}

Table 2. Effect of seed soaking treatments with benzyl adenine, paclobutrazol, algae extract, some elements $(\mathrm{Ca}$, $\mathrm{Mg}$ and $\mathrm{Fe}$ in chelated form) and lithovit on seedling growth (radical and plumule length) of Moringa oleifera at 7,10 and 13 days after soaking grown under laboratory conditions during seasons of 2016 and 2017.

\begin{tabular}{|c|c|c|c|c|c|c|c|c|c|c|c|c|c|}
\hline \multirow[t]{3}{*}{ Characters } & & \multicolumn{6}{|c|}{ Average of radical length $(\mathrm{cm})$ seedling $^{-1}$} & \multicolumn{6}{|c|}{ Average of plumule length $(\mathrm{cm})$ seedling ${ }^{-1}$} \\
\hline & & \multicolumn{12}{|c|}{ Seasons } \\
\hline & & \multicolumn{4}{|c|}{2016} & \multicolumn{2}{|l|}{2017} & \multicolumn{3}{|c|}{2016} & \multicolumn{3}{|c|}{2017} \\
\hline \multirow{2}{*}{ Treatments } & & \multicolumn{12}{|c|}{ Days after soaking } \\
\hline & & 7 & 10 & 13 & 7 & 10 & 13 & 7 & 10 & 13 & 7 & 10 & 13 \\
\hline \multirow[t]{2}{*}{ Control } & $\mathbf{0 . 0}$ & 1.95 & 2.67 & 3.80 & 2.70 & 4.00 & 5.20 & 1.50 & 2.35 & 3.20 & 1.80 & 2.90 & 4.30 \\
\hline & $25 \mathrm{mgl}^{-1}$ & 2.83 & 3.70 & 5.00 & 3.50 & 4.88 & 6.18 & 1.80 & 2.90 & 4.00 & 2.10 & 3.40 & 5.00 \\
\hline \multirow{3}{*}{$\begin{array}{l}\text { Benzyl } \\
\text { adenine }\end{array}$} & $50 \mathrm{mgl}^{-1}$ & 4.00 & 5.00 & 6.39 & 4.90 & & 7.95 & 2.10 & 3.40 & .70 & 2.43 & 3.95 & 5.75 \\
\hline & $100 \mathrm{mgl}^{-1}$ & 5.67 & 7.20 & 9.10 & 6.50 & 8.35 & 10.15 & 2.80 & 4.80 & 6.80 & 3.12 & 5.15 & 7.45 \\
\hline & $5 \mathrm{mgl}^{-1}$ & 1.70 & 2.00 & 3.00 & 1.95 & 2.95 & 3.90 & 1.25 & 1.75 & 2.25 & 1.58 & 2.38 & 3.48 \\
\hline \multirow[t]{3}{*}{ Paclobutrazol } & $10 \mathrm{mgl}^{-1}$ & 1.45 & 1.65 & 2.80 & 1.65 & 2.45 & 3.25 & 1.15 & 1.63 & 2.08 & 1.45 & 2.13 & 3.12 \\
\hline & $20 \mathrm{mgl}^{-1}$ & 1.20 & 1.32 & 2.55 & 1.46 & 2.15 & 2.90 & 1.03 & 1.45 & 1.85 & 1.33 & 1.88 & 2.58 \\
\hline & $5 \mathrm{mll}^{-1}$ & 2.15 & 2.93 & 4.15 & 3.00 & 4.30 & 5.50 & 1.70 & 2.60 & 3.50 & 2.00 & 3.20 & 4.70 \\
\hline \multirow[t]{2}{*}{ Algae extract } & $10 \mathrm{mll}^{-1}$ & 3.00 & 3.88 & 5.30 & 4.00 & 5.44 & 6.84 & 1.93 & 3.10 & 4.27 & 2.25 & 3.65 & 5.35 \\
\hline & $20 \mathrm{mll}^{-1}$ & 4.70 & 6.10 & 7.90 & 5.45 & 7.10 & 8.70 & 2.30 & 4.00 & 5.70 & 2.83 & 4.43 & 6.33 \\
\hline Elements & $500 \mathrm{mgl}^{-1}$ & 3.66 & 4.60 & 6.00 & 4.50 & 6.00 & 7.45 & 2.00 & 3.25 & 4.50 & 2.36 & 3.81 & 5.56 \\
\hline Lithovit & $500 \mathrm{mgl}^{-1}$ & 5.15 & 6.61 & 8.55 & 6.10 & 7.83 & 9.53 & 2.50 & 4.35 & 6.15 & 2.85 & 4.70 & 6.80 \\
\hline L.S.D. & 0.05 & 0.20 & 0.20 & 0.20 & 0.19 & 0.25 & 0.25 & 0.20 & 0.20 & 0.19 & 0.14 & 0.23 & 0.19 \\
\hline
\end{tabular}


3- Absolute growth rate of seedlings:

Absolute growth rate of seedlings related patterns are seen in Table (3) on the results of seed soaking treatments with BA at $\left(25,50\right.$ and $\left.100 \mathrm{mgl}^{-1}\right), \mathrm{PP}_{333}$ at $\left(5,10\right.$ and $\left.20 \mathrm{mgl}^{-1}\right)$, extract of algae at $(5,10$ and 20 mll- ${ }^{1}$ ), mineral elements i.e. ( $\mathrm{Ca}, \mathrm{Mg}$ and Fe chelated) at $500 \mathrm{mgl}^{-1}$ and lithovit at $500 \mathrm{mgl}^{-1}$ at an absolute growth rate $\left(\mathrm{g} \mathrm{day}^{-1}\right)$ of moringa seedling root and stem under the laboratory conditions during the two seasons of 2016 and 2017. The same data shows that the seeds soaking in benzyl adenine solution with varying concentrations tested were the most successful treatment that resulted in the absolute growth rate of the highest seedling values during the two study season.

In this regard, soaking seeds in $100 \mathrm{mgl}^{-1}$ benzyl adenine substantially improved seedling absolute root and stem growth rates after 10 and 13 days following seed treatment in both study seasons followed by lithovit at $500 \mathrm{mgl}^{-1}$, algae extract at $20 \mathrm{mll}^{-1}$, benzyl adenine at $50 \mathrm{mgl}^{-1}$ and mineral elements at $500 \mathrm{mgl}^{-}$ ${ }^{1}$, and benzyl adenine at the lowest concentration at 25 $\mathrm{mgl}^{-1}$ in descending order when compared with the control treatment.

In addition, root seedlings and stem biomass were substantially improved with a number of therapies. It was clear from the same evidence that the calming and important results of the applied treatments greatly increased the growth characteristics of the seedlings.

With respect to the handling of paclobutrazol, it should be observed that the seeds are soaked at varying amounts of paclobutrazol level decreased seedling absolute growth rate compared with the control during both seasons of study.

Table 3. Effect of seed soaking treatments with benzyl adenine, paclobutrazol, algae extract, some elements (Ca, $\mathrm{Mg}$ and $\mathrm{Fe}$ in chelated form) and lithovit on absolute growth rate of roots and stems ( $\left.\mathrm{g} \mathrm{day}^{-1}\right)$ of Moringa oleifera seedlings grown under laboratory conditions during seasons of 2016 and 2017.

\begin{tabular}{|c|c|c|c|c|c|c|c|c|c|}
\hline \multirow{3}{*}{\multicolumn{2}{|c|}{ Characteristics }} & \multicolumn{4}{|c|}{ Absolute growth rate of root } & \multicolumn{4}{|c|}{ Absolute growth rate of stem } \\
\hline & & \multicolumn{8}{|c|}{ Seasons } \\
\hline & & & & & & & & & \\
\hline \multirow{2}{*}{\multicolumn{2}{|c|}{ Treatments }} & \multicolumn{8}{|c|}{ Days after soaking } \\
\hline & & 10 & 13 & 10 & 13 & 10 & 13 & 10 & 13 \\
\hline \multirow[t]{2}{*}{$\overline{\text { Control }}$} & $\mathbf{0 . 0}$ & 0.24 & 0.38 & 0.43 & 0.40 & 0.28 & 0.32 & 0.37 & 0.47 \\
\hline & $25 \mathrm{mgl}^{-1}$ & 0.29 & 0.43 & 0.46 & 0.43 & 0.37 & 0.40 & 0.43 & 0.53 \\
\hline \multirow{3}{*}{ Benzyl adenine } & $50 \mathrm{mgl}^{-1}$ & 0.33 & 0.46 & 0.52 & 0.50 & 0.43 & 0.47 & 0.51 & 0.60 \\
\hline & $100 \mathrm{mgl}^{-1}$ & 0.51 & 0.63 & 0.62 & 0.60 & 0.67 & 0.70 & 0.68 & 0.77 \\
\hline & $5 \mathrm{mgl}^{-1}$ & 0.10 & 0.36 & 0.33 & 0.32 & 0.17 & 0.20 & 0.27 & 0.37 \\
\hline \multirow{3}{*}{ Paclobutrazol } & $10 \mathrm{mgl}^{-1}$ & 0.06 & 0.34 & 0.27 & 0.27 & 0.16 & 0.18 & 0.23 & 0.33 \\
\hline & $20 \mathrm{mgl}^{-1}$ & 0.04 & 0.32 & 0.23 & 0.25 & 0.14 & 0.17 & 0.18 & 0.23 \\
\hline & $5 \mathrm{mll}^{-1}$ & 0.26 & 0.44 & 0.44 & 0.42 & 0.30 & 0.33 & 0.40 & 0.50 \\
\hline \multirow{2}{*}{ Algae extract } & $10 \mathrm{mll}^{-1}$ & 0.29 & 0.46 & 0.48 & 0.47 & 0.39 & 0.42 & 0.47 & 0.57 \\
\hline & $20 \mathrm{mll}^{-1}$ & 0.46 & 0.60 & 0.55 & 0.53 & 0.57 & 0.60 & 0.53 & 0.63 \\
\hline Elements & $500 \mathrm{mgl}^{-1}$ & 0.31 & 0.45 & 0.50 & 0.48 & 0.42 & 0.45 & 0.48 & 0.58 \\
\hline Lithovit & $500 \mathrm{mgl}^{-1}$ & 0.49 & 0.62 & 0.58 & 0.57 & 0.62 & 0.63 & 0.62 & 0.70 \\
\hline L.S.D. at & 0.05 & 0.05 & 0.06 & 0.08 & 0.05 & 0.09 & 0.09 & 0.05 & 0.10 \\
\hline
\end{tabular}

\section{Discussion}

Such enhancing effect of using BA, algae extract, mineral nutrients and lithovit on germination of seed and seedling growth parameters may be qualified to the main role of such growth enhancement substances on the regulation of meristematic cell division, cell enlargement, differentiation activity and organogenesis in the evolving plants, which in turn may stimulate plant growth rate.

The promotive effects of BA on accelerating and increasing seeds germination $\%$, rate and seedling growth traits of Moringa oleifera in the current study attributed to the significant role of cytokinins in the formation of hydrolytic enzymes activates for the mobilization of reserve in germination seeds. Also, benzyl adenine has important role on synthesis of enzyme protein by messenger RNA and DNA synthesis. Hence, reflected on germination processes and in the subsequent development of the seedling. Plant hormones have cytokinins, are biochemical substances regulatory many physiological and biochemical processes in the plant (Werner et al., 2001). Cytokinins are regulating a range of plant activities including seed germination (Graeber et al., 2012). They are active in all periods of germination (Chiwocha et al., 2005), (Nikolic et al., 2006 ), (Riefler et al., 2006 ). Different actions of cytokinins, such as their properties on seed germination, have been attributed to the several functions of cytokinins in different plant cell types. They can also affect the activities of meristemic cells in roots and shoots.

Cytokinins also, has a regulatory role in the translation of genetic code into new protein (Purohit 2007). Several researches showed that cytokinins have a very active metabolism roles in all phases of germination from imbibition to radical emergence and the start of seedling establishment (Stirk et al., 2005) 
and (Nikolic et al., 2006). In this respect, (Patil et al., 2012) found that all used types and concentration of BA and auxins were able to accelerate the germination rate and increases seed germination $\%$ and seedlings growth of Digitalis puerperal.

These results of BA are in harmony with those reported by (Du and Tuong 2002), (Harris et al., 2002), (Ismaeil 2004), (Afzal et al., 2008), (Chiwocha et al., 2005 ), (Farooq et al., 2005 ), ( Nikolic et al., 2006), (El-Desoky 2013) and (Ahmed et al., 2014).

The simulative favorable effect of algae extract in present investigation on personally seeds germination rate and \%, in addition, seedlings growth parameters may be due to its content of the plant growth promoting constituents such as cytokinins, auxins, gibberellins, amino acids, vitamins and enzymes which reflected on enhancing of seeds germination \% and rate as well as seedlings growth by effecting on activities of many enzymes and with cell division and cell expansion.

Many studies have evaluated the helpful effects of different algael extracts on improving seeds germination and seedling growth by (Thirumaran $\boldsymbol{e t}$ al., 2009) and (Cherian et al., 2011) they showed that the seaweed extract promoted seeds germination $\%$ and rate as well as seedling growth (shoot length and root length) of rice seeds.

Similarly, (Arun et al., 2014) showed that rate and $\%$ of seeds germination and seedlings growth of tomato and okra seeds were increased by low concentration of seaweed extract, but it reduces at higher level. The applying of seaweed extract improves seeds and seedling development and stimulates rooting (Zhang and Errin 2008).

The aforementioned results of algae extract are in conformity with those obtained by (Pascale $\boldsymbol{e t}$ al., 1993), Sunarpi et al., (2007), (Zhang and Errin 2008) and (Arun et al., 2014). Such enhancing effects of lithovit and mineral nutrients $(\mathrm{Ca}, \mathrm{Mg}$ and $\mathrm{Fe}$ chelated) on seeds germination process and seedlings growth due to the functions of these mineral nutrients in cell metabolism and effects as a metal component of some enzymes and during seeds germination (Marschner 1995).

Such results of lithovit have been earlier recommended by (Lu et al., 2002), (Prasad et al., 2012), (Yugandhar and Savithramma 2013), ( Hojjat 2015) and (Abdel ghafar et al., 2016). They found that treatment of nanoscales promoted both seed germination and seedling vigour and proved effective on increasing stem and root growths.

In this respect, (Abdel ghafar et al., 2016) presented that lithovit application with $0.5 \mathrm{~g} / \mathrm{L}$ significantly affected on seed germination \% of onion plants. (Yugandhar and Savithramma 2013) showed that the biosynthesized calcium carbonate nanoparticles accelerate the seed germination and seedling growth of Vigna mango and the highest percentage of seed germination, seedling vigor index, root and shoot length were recorded from synthesized CCNPS treatment.

On the other side, such reduction and delayed seeds germination rate and percentage as well as seedlings growth aspects in the abovementioned results with paclobutrazol treatments may be attributed to that paclobutrazol in a common is antigibberellin and inhibits gibberellin biosynthesis, later reducing cell elongation and retarding plant growth (Rademcher 2000).

Since, the stimulating effects of gibberellin on germination process due to fact that $\mathrm{GA}_{3}$ affects on activities of many enzymes and control production of hydrolyzing enzymes involved in germination process $\mathrm{GA}_{3}$ also induces substrate mobilization. In addition, one of the effects of $\mathrm{GA}_{3}$ is to promote the onset of DNA synthesis in cells which are arrested a $G_{1}$ phase of cell cycle.

$\mathrm{GA}_{3}$ can promote the growth of plant by affecting either cell expansion and or cell division or both (Purohit 2007).

On the contrary, paclobutrazol completely reversed these effects of gibberellin. Hence, it decreased seeds germination $\%$ and rate as well as seedling vigour growth of moringa plants these results are in agreement with those obtained by (Marshall $\boldsymbol{e t}$ al., 2000), (Rademacher 2000), (Ismail 2004), (Mijajlović et al., 2005), (Müller 2007) and (Abd ElGwad 2006) they reported that treatment of seeds with paclobutrazol delayed germination and decreased root and shoot extension.

\section{References}

Abd El-Gawad, H. A. (2006): Growth performance of black cumun (Nigella sativa L.) plants using certain growth conditions. Ph.D. Thesis, Fac. of Agric., Moshtohor, Benha Univ.

Abdel ghafar, M.S; M.T. Al-Abd; A.A. Helaly and A.M. Rashwan (2016): Foliar application of lithovit and rose Water as factor for increasing onion seed production, Nat.sci. 14(3): 53-61.

Abdul Baki, A.A. and J.D. Anderson (1973): Vigour determination in soybean seed by multiple criteria. Crop Sci., 13: 630-633.

Afzal, I., S. M. A. Basra, M. Shahid and M. Saleem (2008): Priming enhances germination of spring maize (Zea mays L.) under cool conditions. Seed Sci. Technol., 36: 497-503.

Ahmed, L. T., E. I. Warrag and A. Y. Abdelgadir (2014): Effect of shade on seed germination and early seedling growth of Moringa oleifera Lam. Journal of Forest Products \& Industries, 3 (1): 2026.

Ahmed, Y. M. and E. A. Shalaby (2012): Effect of different seaweed extracts and compost on vegetative growth, yield and fruit quality of cucumber, J. Hort. Sci. \& Ornamen. Plants, 4 (3): 235- 240.

Anwar, F., M. Ashraf, M. I. Bhanger (2005): 
Interprovenance variation in the composition of Moringa oleifera oilseeds from Pakistan. J. Am. Oil Chem. Soc., 82:45-51.

Arun, D. P. K. Gayathri, M .Chandran and D. Yuvaraj (2014): Studies on effect of seaweed extracts on crop plants and Microbes. Int. J. Chemtech Res., 6 (9): 4235- 4240.

Basra, S. M. A., M. Farooq, R. Tabassum and N. Ahmad (2005): Physiological and biochemical aspects of seed vigour enhancement treatments in fine rice (Oryza sativa L.). Seed Sci. Technol., 33: 623- 628.

Basra, S. M. A., M. Farooq, A. Wahid, and M. B. Khan (2006): Rice seed invigoration by hormonal and vitamin priming. Seed Sci. Technol., 34: 775780.

Cairo, P. A. R., L. E. M. Oliveira and A. C. Mesquita (2008): Analise de crescimento de plants. Vitoria da Conquista: Edicoes UESB, P.72.

Cherian, K.J., K.S. Vishwa and P.C. Shahare (2011): Effect of algal extract on the germination and seedling growth of rice seeds. Bionano Frontier, 4(1) Jan.

Chiwocha, S. D., A. J. Cutler, S. R. Abrams, S. J. Ambrose and J. Yang (2005): The etr12mutation in Arabidopsis thaliana affects the abscisic acid, auxin, cytokinin andgibberellin metabolic pathways during maintenance of seed dormancy, moist-chilling and germination. Plant J., 42: 35- 48.

Du, L.V. and T. P. Tuong (2002): Enhancing the performance of dry-seeded rice: effects of seed priming, seedling rate, and time of seedling. In: Direct Seeding: Research Strategies and Opportunities (Eds. S Pandey, M Mortimer, L Wade, TP Tuong, K Lopes, B Hardy). International Research Institute, Manila, Philippines, 241- 256.

Durand, N., X. Briand and C. Meyer (2003): The effect of marine bioactive substances (NPRO) and exogenous cytokinins on nitrate reductase activity in Arabidopsis thaliana. Physiol. Plant, 119:489493.

Edmond, J.B. and W.J. Drapala (1958): The effect of temperature, sand and soil and aceton on germination of akrea seeds. proc. Amer. Soc. Hort. Sci.,71: 428- 438.

EL-Desouky, H. S. A. (2013): Botanical studies on some citrus root stocks. M. Sc. Thesis, Fac. of Agric., Moshtohor, Benha Univ.

Fahey, J. W. (2005): Moringa oleifera: A review of the medical evidence for its nutritional, therapeutic, and prophylactic properties. Trees for Life Journal, 1: 1-5.

Farooq, M., S. M. A. Basra and H. Rehman (2006b): Seed priming enhances emergence yield and quality of direct seeded rice. Int. Rice Res Notes, 31: 42- 44.

Farooq, M., S. M. A. Basra, H. Rehman and M. Hussain (2008): Seed priming with polyamines improve the germination and early seedling growth in fi ne rice. J. New Seeds 9:145-155.

Farooq, M., S. M. A. Basra, K. Hafeez and N. Ahmad (2005): Thermal hardening: a new seed vigor enhancement tool in rice. J. Integ. Plant Biol., 47: 187-193.

Graeber, K., K. Nakabayashi, E. Miatton, G. Leubner-Metzger and W. Soppe (2012): Molecular mechanisms of seed dormancy. Plant Cell Environ., 35, 1769-1786.

Harris, D., R. S. Tripathi and A. Joshi (2002): Onfarm seed priming to improve crop establishment and yield in dry direct-seeded. In: Direct Seeding: Research Strategies and Opportunities (Eds. S Pandey, M Mortimer, L Wade, TP Tuong, K Lopes, B Hardy). International Rice Research Institute, Manila, Philippines, 231-240.

Hojjat, S. S. (2015): Impact of Silver Nanoparticles on Germinated Fenugreek Seed, Intl. J .Agri. Crop Sci., 8 (4): 627- 630.

Ismail, T.B.A. (2004): Effect of drip irrigation rates, organic fertilization and plant density on yield and quality of snap bean. Ph. D. Thesis Fac. of Agric. Suez Canal Univ. Egypt.

Jahn, S. A., H. A. Musnad and H. Burgstaller (1986): The tree that purifies water: cultivating multipurpose Moringaceae in the Sudan. Unasylva, 38: 23-28.

Lu, C. M., C. Y. Zhang, J. Q. Wen, G. R. Wu and M. X. Tao (2002): Research of the effect of nanometer materials on germination and growth enhancement of Glycine max and its mechanism. Soya Bean Science, 21: 168-172.

Marschner, H., (1995): Mineral nutrition of higher plants. 2nd ed., Acadimic press. Pub. New York (USA).

Marshall, J., T. Beardmore, C. A. Whittle, B. Wang, R. G. Rutledge and E. Blumwald (2000): The effects of paclobutrazol, abscisic acid, and gibberellin on germination and early growth in silver, red, and hybrid maple. Can. J. For. Res., 30: 557- 565 .

Mijajlovič1, N., D. Grubišić, Z. Giba and R. Konjević (2005): The effect of plant growth regulators on centaury (Centaurium erythraea rafn.) seed germination, Arch. Biol. Sci., Belgrade, 57 (1): 25- 28.

Müller, C. (2007): Efeito do paclobutrazol na germinação e no metabolismo do etileno em sementes de Stylosantes humilis HBK. M.Sc. Dissertation, Universidade Federal de Viçosa, Viçosa.

Nel, A., T. Xia, L. Madler and N. Li. (2006): Toxic potential of materials at the nanolevel. Science, 311: 622- 627.

Nikolic, R., N. Mitic, R. Miltic, and M. Neskovic (2006): Effects of cytokinins on in vitro seed germination and early seedling Morphogenesis in Lotus cornice - Latus L. J. plant Growth Regulation, 25: 187-194. 
Ördög, V., W.A. Stirk, J. van Staden, O. Novak and M. Strnad (2004): Endogenous cytokinins in the three genera of microalgae from the Chlorophyta. J. Phycol., 40:88-95.

Palada, M. C. and L. C. Chang (2003): Suggested Cultural Practices for Moringa. International Cooperator's Guide. Asian Vegetable Research and Development Center, Shanhua, Taiwan.

Pascale, P., J. Claude, B. Kloareg, Y. Lineart and C. Rochans (1993): Seaweed liquid fertilizer from Ascophyllum nodosum contains elicitor of plant dglycanase. J. Appl. Phycol., 5: 343-349.

Patil, J.G., M.L. Ahire and T.D. Nikam (2012): Influence of plant growth regulators on in vitro seed germination and seedling development of Digitalis purpurea L. the Asian and Australasian, J. of plant sci. and Biotech., 6 (1): 12-18.

PGRSA (2007): Plant growth regulation handbook of the Plant Growth Regulation Society of America. $4^{\text {th }}$ Edition. The Plant Growth Regulation Society of America, Ath-ens.

Prasad, T. N. V. K. V., P. Sudhakar, Y. Sreenivasulu, P. Latha, V. Munaswamy, K.R. Reddy, T. S. Sreeprasad, P. R. Sajanlal and T. Pradeep (2012): Effect of Nanoscale Zinc oxide particles on the germination, growth and yield of peanut, Journal of Plant Nutrition, 35: 905-927.

Purohit, S. S. (2007): Plant physiology Published by Student Edition, Jodhpur 342003 India.

Rademacher, W., (2000): Growth retardants: effects on gibberellin biosynthesis and other metabolic pathways. Ann. Rev. Plant Physiol., 51: 501- 531.

Riefler, M., O. Novak, M. Strnad and T. Schmulling(2006): Arabidopsis cytokinin receptor mutants reveal functions in shoot growth, leaf senescence, seed size, germination, root development, and cytokinin metabolism. Plant Cell, 18:40-54.

Scott;S.J., R.A. Jones and W.A. Williams (1984): Review of data analysis methods for seed germination, Crop. Sci., 24 : 1192-1199.

Sharma, G. K. and V. Raina (1982): Propagation techniques of Moringa oleifera Lam. In: Improvement of Forest Biomass: Proceedings of a Symposium (Ed. PK Khosla). Solan, India, 175181.

Siddhuraju, P and K. Becker. (2003): Antioxidant properties of various solvent extracts of total phenolic constituents from three different agro climatic origins of drumstick tree (Moringa oleifera Lam.) leaves. J. Agric. Food Chem., 51: 2144- 2155.

Snedecor, G. W. and Cochran, W. G. (1989): Statistical methods. $7^{\text {th }}$ Ed. Iowa State Univ. Press Ames. Iowa, USA.

Stirk, W.A., Novak, M.S. and van Staden, J. (2003): Cytokinins in macroalgae. Plant Growth Regul., 41:13-24.

Strik, W.A; Gold,J.D ; Novak, O; Strnad, M and Van staden, J (2005): Changes in endogenous cytokinins during germination and seedling establishment of Togetes minuta L. plant growth Regulation, $47: 1-7$.

Sunarpi, Jupri, A. and Nurahman (2007): Screening of west Nusa Tenggara seaweed that potential as raw materials of organic fertilizer. Faculty of Mathematics and Natural Sciences, University of Mataram. Mataram. Indonesia.

Tedonkeng, P.E., Boukila, B., Solefack, M.M.C., Kana, J.R. , Tendonkeng, F. and Tonfack, L.B. (2004): Potentiel de germination de Moringa oleifera Lam. sous different treatments a Dsc hang dans les Hautes terres de l'Ouest- Cameroun [Germination potential of Moringa oleifera Lam. under different treatments in DSc hang in the highlands of western Cameroon]. J Camer Acad Sci., 4: 199-203.

Thirumaran, G; M. Arumugam; R. Arumugam and P. Anantharaman (2009): Effect of seaweed liquid fertilizer on growth and pigment concentration of Cyamopsis tetrogonolaba L, Taub. Am. Euras. J. Agron., 2 (2): 50-56.

Werner, T., Motyka, V., Strnad, M. and Schmulling, T. (2001): Regulation of plant growth by cytokinin. Proc. Nat. Acad. Sci. U.S.A., 98, 10487-10492.

Yugandhar, P. and N. Savithramma (2013): Green synthesis of calcium carbonate nanoparticles and their effects on seed germination and seedling growth of Vigna mungo (L.). Hepper. Inter. J. of Advanced Res., 1 (8):89-103.

Zhang, X; E. H. Errin. (2008): Impact of seaweed extract-based cytokinins and zeatin riboside on creeping bentgrass heat tolerance. Crop Sci., 48: 364-370. 
تأثير نقع البذور بالبنزيل أدنين و الباكلويترازول و مستخلص الطحالب و بعض العناصر الغذائية والليثوفيت على إنبات بذور ونمو بادرات نبات المورينجا.

حسنى محمد محمد عبدالايم ، فاتن حسن محمود إسماعيل، محمد محمد محمود عبدالعال، رانيا سعيد معوض عيدات باتيات

قسم النبات الزراعى - كلية الزراعة - جامعة بنها - مصر.

أجريت تجربتين معمليتين بقسم النبات الزراعى - كلية الزراعة - جامعة بنها - محافظة القليوبية - مصر خلال موسمى 2016 ، 2010 ،

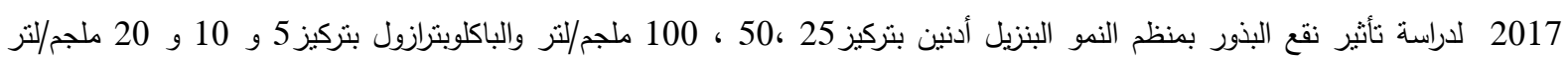

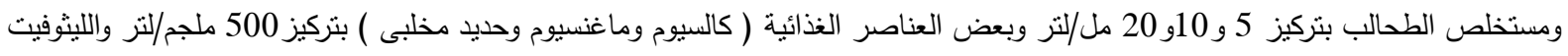
بتركيز 500 ملجم/ لتز مقارنة بالكنترول (ماء الصنبور ) على نسبة إنبات البذور ونمو البادرات لنبات المورينجا.

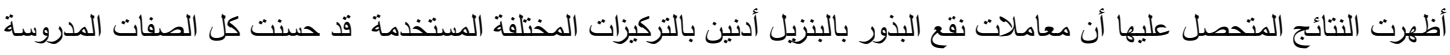

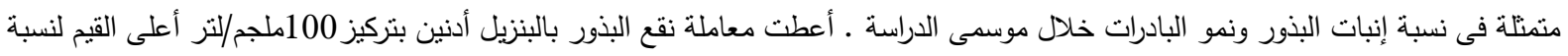

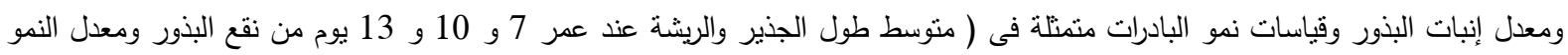

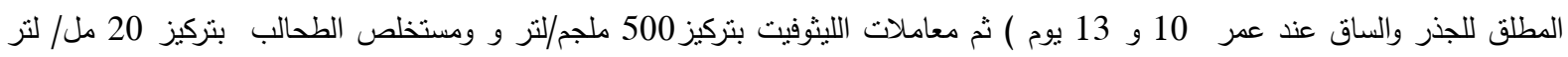
والبنزيل أدنين بتركيز 50 ملجم/لتز والعناصر الغذائية ( كالسيوم وماغنسيوم وحديد مخلبى ) بتركيز 500 ملجم/تلنز والبنزيل أدنين بتركيز 25ملجم/

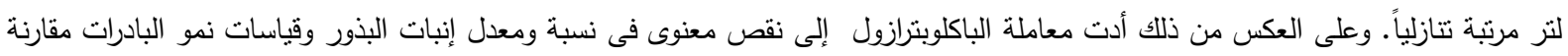
بالكنترول خلال موسمى الدراسة. 